症例

リネゾリド長期投与により臨床的寛解を得た 塩酸バンコマイシン不応性 MRSA 化膿性脊椎炎の 1 例

\author{
直方中央病院外科 \\ 赤川進新山秀昭
}

症例は84歳，女性。発熱と咳嗽，腰背部痛を主訴に当院入院となり，MRSA 肺炎の診 断で塩酸バンコマイシン ( VCM) 等の抗生剂治療を行った。肺炎は軽快したが炎症反応 の改善に乏しく, 腰背部痛も持続していたため腹部 CT, 春椎 MRI を施行した。その結 果, L1-2椎体の化膿性春椎炎, 硬膜外膿瘍および連続する両側腸腰筋膿瘍を認めた. CT ガイド下に腸腰筋膿瘍をドレナージし, MRSA が検出され, MRSA 化膿性脊椎炎と診断 した。ドレナージ後より VCM を継続投与したが一度低下した炎症反応が再上昇し, VCM 不応性と判断し，骨軟部組織移行性に優れたリネゾリド (LZD) に変更した。 LZD を28日間投与した時点で CRP の陰性化は得られなかったが，以後抗生剤を投与せず経 過観察した。その後 8 カ月が経過したが化膿性脊椎炎の再燃を認めず，臨床的寛解を得 たと判断した。

索引用語：リネゾリド，MRSA，化膿性脊椎炎

\section{緒 言}

近年, 高齢化, 易感染性宿主の増加, 而性菌の増加 などにより本邦では化膿性脊椎炎は増加傾向にあり, 治療に難渋することが多い。今回われわれは，塩酸バ ンコマイシン (VCM) 不応性 MRSA 化膿性春椎炎に 対し，リネゾリド (LZD) 長期投与により臨床的寛解 を得た症例を経験したので，文献的考察を含めて報告 する。

患者：84歳, 女性.

\section{症例}

主訴: 発熱, 咳嗽, 腰背部痛.

家族歴：特記すべきことなし.

既往歴：総胆管結石に対して平成 20 年 5 月に内視鏡 的採石術施行.

入院時現症： $142 \mathrm{~cm}, 46 \mathrm{~kg} .38 .5^{\circ} \mathrm{C}$, 血圧 $140 / 90$ $\mathrm{mmHg}$, 脈拍 90 回/分, 呼吸数 12 回/分, 経皮的動脈血 酸素飽和度 $94 \%\left(\mathrm{O}_{2} 2 \mathrm{~L} /\right.$ 分投与).

入院時血液生化学検査: WBC $21,000 / \mu 1$, CRP $25.1 \mathrm{mg} / \mathrm{dl}$ と高度炎症所見を認めた。また低蛋白血

2010年 2 月 18 日受付 2010 年 4 月 22 日採用

〈所属施設住所〉

干822-0001 直方市大字感田523-5
症, 軽度貧血, 腎機能障害も認めた。

入院経過：平成 20 年 6 月上旬より肺炎の診断で入 院. セフタジジム (CAZ) 2.0g/day と塩酸クリンダマ イシン (CLDM) 1.2g/day を投与中であったが，喀痰 培養で MRSA が検出されたためVCM $1.0 \mathrm{~g} /$ day と パニペネム・ベタミプロン (PAPM/BP) $1.0 \mathrm{~g} / \mathrm{day} を$ 開始した（Fig. 1)。画像上，肺炎像は軽快したが炎症 反応高值が継続し, 難治性腰背部痛も認めるため腹部 CT を施行したところ，両側腸腰筋膿瘍を認めた(Fig. 2). MRI では両側腸腰筋膿瘍に連続する L1-2椎体の 化膿性脊椎炎，硬膜外膿瘍を認めた（Fig. 3a， b). そ のため 7 月中旬に CT ガイド下腸腰筋膿瘍ドレナージ を施行し, 膿瘍培養と血液培養で MRSA が検出され, MRSA 化膿性脊椎炎と診断した. VCM 投与を継続し たが CRP 值の再上昇を認めたため, VCM 不応性とな つたと判断し, LZD 1.2g/day を投与開始した.28日間 投与し，CRP 值は $1.7 \mathrm{mg} / \mathrm{dl}$ まで低下した。 CRP 值は 陰性化しなかったが，以後抗生剂を使用せず経過観察 した. LZD 投与後 6 力月目の MRI (Fig. 4a， b) で両 側腸腰筋膿瘍は消失しており, 臨床上, 炎症の再燃を 認めないまま 8 カ月が経過した。

考察

化膿性脊椎炎は易感染性宿主の増加に伴い近年増加 


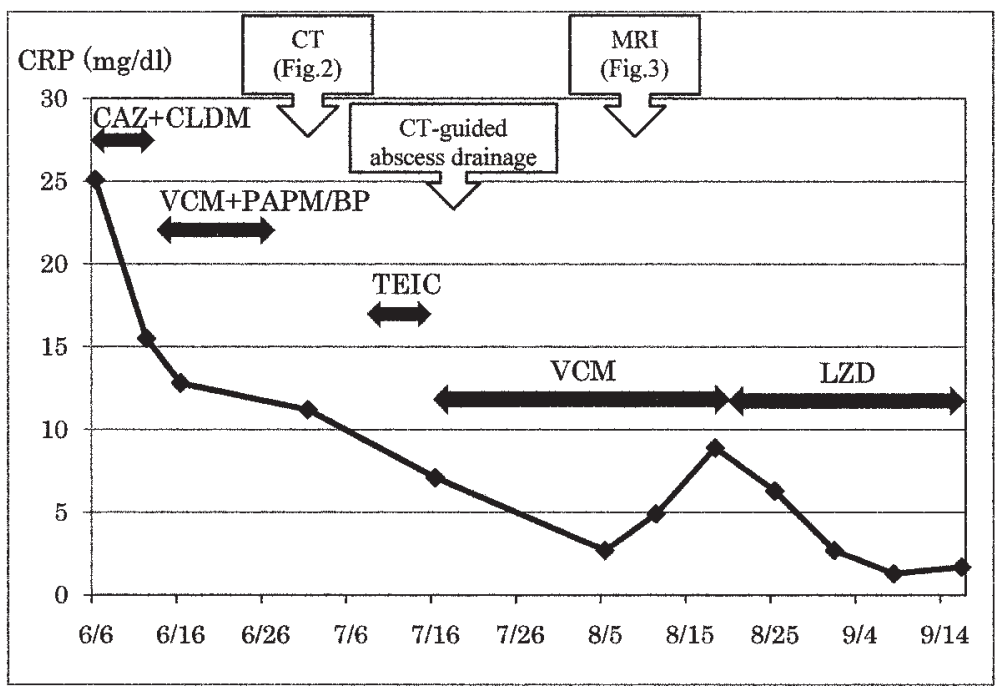

Fig. 1 : Clinical course during therapy.

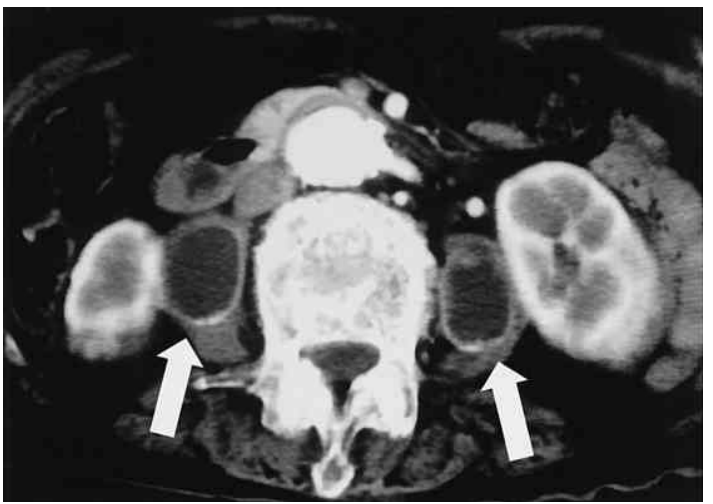

Fig. 2: Abdominal CT showing the iliopsoas muscle abscess (arrow).

傾向にある ${ }^{1)}$. 強い腰背部痛や発熱などの典型的な臨 床像を呈するような症例では, MRI により比較的早期 に診断が可能とされているが，実際には対症的に抗生 剂や消炎鎮痛剤が先行投与されていることが多く，化 膿性脊椎炎と診断されるまでに長期間を要する場合も 多い2). このため MRSA 等の耐性菌も近年増加傾向に あり，これまで以上に治療が困難となりつつある ${ }^{3) 4}$. 治療は，神経症状を認めない場合まずは保存的に患部 の安静と抗生剤投与を行い, 保存的治療抵抗性の場合 は経皮的病巣搔爬ドレナージが有効とされ，神経症状 を認める場合には椎体進入手術や instrumentation 手 術などの外科的治療が行われている(4) 8). 自験例では
入院時より腰背部痛と発熱を認めていたが，疼痛が急 性発症でなく変形性春椎症を伴っていたこと, 当初は 肺炎が炎症の主座となっていたこと, 肺炎治療中に抗 生剤を継続投与していたことなどから，診断確定まで に約 1 力月を要した。また化膿性脊椎炎の症例の約半 数で硬膜外膿瘍や腸腰筋膿瘍を併発すると報告されて いるが，本症例でも両側腸腰筋膿瘍を認めたため，膿 瘍穿刺ドレナージが必要であった ${ }^{910)}$. しかし, 麻痺な ぞの神経症状は出現していなかったため, それ以上の 外科的治療は追加せず保存的治療を行った。

自験例では血液培養と腸腰筋膿瘍培養で MRSA が 検出され MRSA 化膿性脊椎炎と診断したが，MRSA 化膿性脊椎炎の特徵として, 非 MRSA 化膿性脊椎炎 に比べて易感染性宿主の割合が多いこと, MRSA 肺炎 などの先行感染が多いこと，膿瘍合併の頻度が多いこ となどが報告されている ${ }^{11}$ 。また一般に MRSA 化膿 性脊椎炎の治療にはVCM や硫酸アルベカシン

(ABK) などの抗 MRSA 薬の長期投与が必要とさ れ，保存的治療抵抗性の症例では外科的治療が選択さ れている ${ }^{11)}$. 自験例では, MRSA 化膿性脊椎炎と診断 されるまでに VCM とテイコプラニン (TEIC) を使用 し，診断確定後はVCM を継続投与していたが，CRP 值の再上昇を認めたため治療方針を見直す必要があっ た。画像上，MRI では化膿性春椎炎および硬膜外膿瘍 の明らかな増悪は認められなかったが，改善傾向もな かったため VCM の継続投与では治癒困難と判断し, 

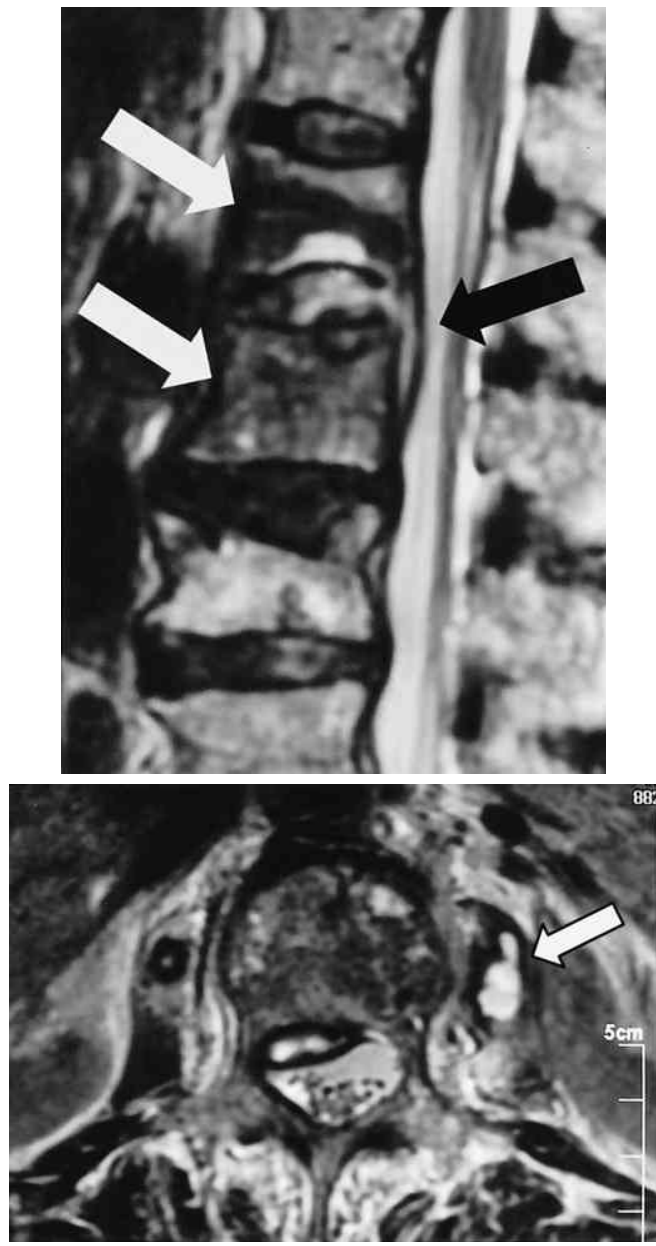

Fig. 3: T2-weighted MR images obtained in August 2008.

(a) : There are unequal high intensity areas at L1 and L2 (white arrow). In addition, there is an epidural abscess (black arrow).

(b): There is an iliopsoas muscle abscess (arrow)

$\frac{\mathrm{a}}{\mathrm{b}}$

ABK や2006年に保険適応となった LZD の投与を検 討した。『リネゾリド』,『MRSA』, 『脊椎感染症』をキ ーワードに2005年から2010年まで医学中央雑誌で検索 しえた範囲では，LZD を MRSA 春椎感染症に使用し た報告は福永ら ${ }^{12)}$ の報告のみであった。福永らの 5 例 の報告では LZD 投与後 5 例全例で CRP は陰性化し ており, 他の抗 MRSA 薬不応性の MRSA 脊椎感染症 に対する LZD の有用性が示唆されていた ${ }^{12)}$ 。また， LZD は骨軟部組織への移行性が良好であるという特
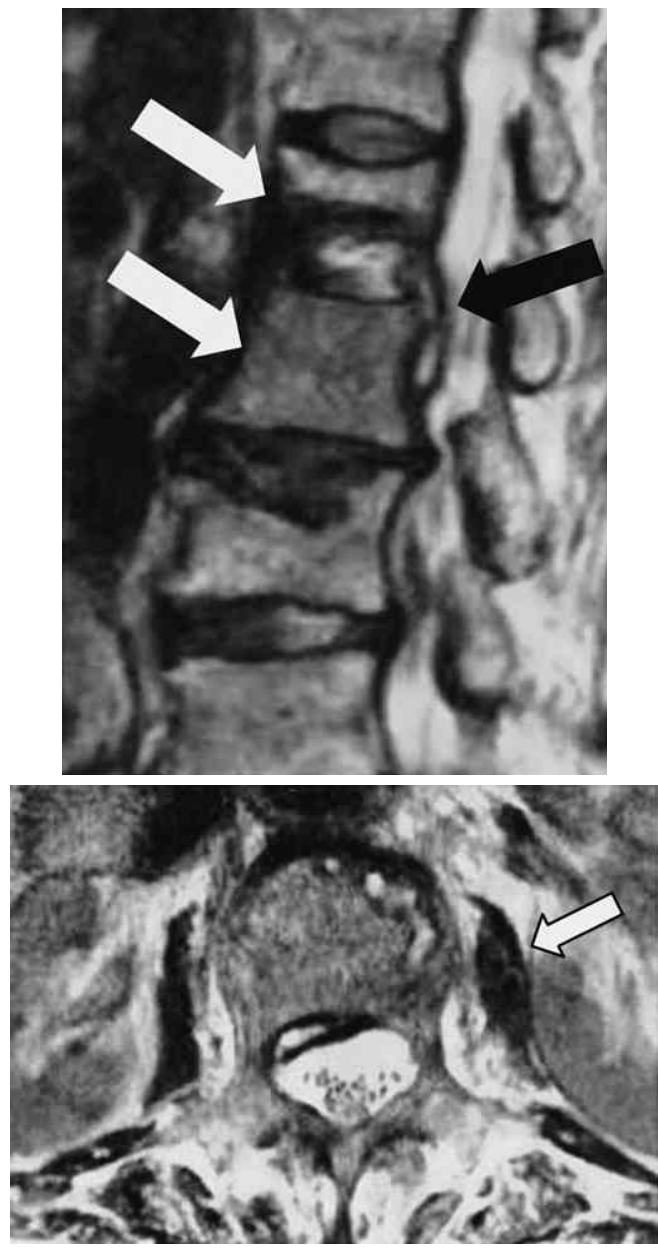

Fig. 4 : T2-weighted MR images obtained in March 2009.

(a) : The abnormal signal area located at L1 and L2 has improved (white arrow); the epidural abscess has diminished (black arrow).

(b) : Iliopsoas muscle abscess is no longer present (arrow).

$\frac{\mathrm{a}}{\mathrm{b}}$

徵を持っているため ${ }^{13)}$ ，自験例では抗 MRSA 薬を $\mathrm{VCM}$ から LZD に変更したところ，以後 CRP 值は漸 減した。化膿性脊椎炎に対する抗生剂投与期間につい ては統一した見解が得られていないが，CRP 值が0.2 $\mathrm{mg} / \mathrm{dl}$ 以下となった時点で投与終了とする場合が多 ( ${ }^{14)}$. 自験例では，投与 28 日目には CRP 值が $1.7 \mathrm{mg} /$ dl まで低下したが $0.2 \mathrm{mg} / \mathrm{dl}$ 以下にはならなかった。 しかし，LZD の28日を超える投与は日本医薬品集医療 薬2008年版で視神経障害発現の危険があると警告され 
ており，また腰背部痛や発熱などの臨床所見が軽快し ていたことから，LZD 投与は28日間で終了とした。 LZD 投与終了後 3 力月目の MRI で腸腰筋膿瘍の消失 を認め，6力月目の MRI では LZD を投与していない にもかかわらず，T2強調画像で認められていた L1-2 椎体の不均一高信号域が軽減し, 硬膜外膿瘍も縮小し ていた。多剤耐性菌による骨髄炎に対して LZD を投 与した Rayner ら ${ }^{15)}$ の報告では, LZD 投与終了後 8 力 月経過時点で 8 割以上が寛解したと報告しており, 再 燃例は 5 力月目以降認められていない. 本症例は LZD 投与終了後 5 力月以上経過するも画像上再燃を認め ず，また炎症反応の再上昇や腰背部痛などの臨床所見 も出現しないまま 8 力月が経過したため, この LZD 投与終了後 8 力月経過した時点で臨床的寛解が得られ たと判断した。 MRSA 化膿性脊椎炎に対して LZDを 保険適応内の 28 日間投与し, その後 8 力月以上臨床的 寛解が得られている本症例は示唆に富む 1 例と考えら れたため報告した。

\section{結語}

難治性の MRSA 化膿性脊椎炎に対し LZD を保険 適応内の 28 日間投与することで臨床的寛解が得られた 1 例を報告した。

\section{文献}

1）赤木繁夫 : 脊椎感染症の病態生理. 脊椎脊髄ジャ ーナル 2005；20：949-950

2) Modic MT, Feiglin DH, Piraino DW, et al: Vertebral osteomyelitis : assessment using MR. Radiology 1985 ; 157 : 157-166
3）赤木繁夫：脊椎感染症の早期診断. 整・災外 $2009 ； 52 ： 11-19$

4）佐藤公昭, 永田見生：最近の化膿性脊椎炎の動向. 整・災外 $2009 ; 52: 21-28$

5) Safran O, Rand N, Kaplan L, et al : Sequential or simultaneous, same-day anterior decompression and posterior stabilization in the management of vertebral osteomyelitis of the lumbar spine. Spine $1998 ; 23: 1885-1890$

6）若林 徹，小保方浩一，田島正稔他：最近 7 年間 における化膿性脊椎炎の診断および保存的治療. 整形外科 $2007 ; 58 ： 257-259$

7）中川晃一，池田光正，福田寛二他：当科における 化膿性春椎炎治療の検討。骨関節感染症 2008 ; $22: 67-69$

8）小久保吉恭，山崎隆志，佐藤 茂：化膿性脊椎炎 の臨床像。整形外科 $2008 ； 59 ： 1297-1303$

9）直樹邦夫, 秦良一郎, 石根正博他：化膿性春椎炎腰筀膿瘍に対する CT 下穿刺. 臨放 2003；48： 1096-1102

10）前田 崇，市本裕康，齊鹿 稔：化膿性脊椎炎の 治療経験. 西日脊椎研会誌 $2008 ； 34 ： 45-48$

11）青木隆明, 大澤良充, 井上英則他：MRSA 化膿性 春椎炎 5 例の検討. 東海脊椎外 $2007 ； 21 ： 90-$ 92

12）福永絵里奈, 川内義久, 鮫島浩司他：リネゾリド が有効であった MRSA 脊椎感染症の治療経験. 整・災外 $2009 ; 58: 7-9$

13) Rana B, Butcher I, Grigoris P, et al : Linezolid penetration into osteo-articular tissues. J Antimicrob Chemother 2002; $50: 747-750$

14）永島英樹：春椎感染症に対する治療戦略. 整・災 外 $2009 ; 52: 29-34$

15) Rayner CR, Baddour LM, Birmingham MC, et al : Linezoid in the treatment of osteomyelitis : Results of compassionate use experience. Infection $2004 ; 32: 8-14$

\title{
A CASE OF MRSA VERTEBRAL OSTEOMYELITIS NOT RESPONDING TO VANCOMYCIN BUT SUCCESSFULLY TREATED WITH LINEZOLID
}

\author{
Shin AKAGAWA and Hideaki NIIYAMA \\ Department of Surgery, Nogata Central Hospital
}

An 84-year-old woman was admitted due to pyrexia, cough, and a lumbar backache. She was treated with vancomycin $(\mathrm{VCM})$ under the diagnosis of methicillin-resistant staphylococcus aureus (MRSA) pneumonia. Despite the fact that her pneumonia resolved, her inflammatory marker levels remained high. Abdominal CT and spinal MRI demonstrated a first and second lumbar vertebral osteomyelitis, as well as an extradural abscess communicating with an iliopsoas muscle abscess. MRSA vertebral osteomyelitis was definitively diagnosed on examination of fluid obtained from the iliopsoas muscle abscess. Systemic VCM was changed to systemic linezolid (LZD) due to LZD's excellent penetration into osteo-articular tissues. Inflammatory markers gradually decreased during LZD treatment; LZD was given for 28 days. 8 months after LZD treatment, reactivation of the MRSA vertebral osteomyelitis has not occured; additional LZD other antibiotic treatment did not need to be given.

Key words : linezolid, MRSA, vertebral osteomyelitis 